\title{
Perlindungan Hukum Merek Terkenal di Indonesia
}

\author{
Ridwan Khairandy
}

\begin{abstract}
Abstrak
Indoniesian Trademark law related to the represive protection limits itself to the legal protection for like products or services. In fact, there have been many products or services using illegal well-know marks for unlike products or services. Before law 1992 No. 19 jo law 1997 No. 14, in many cases, courts extended legal protection to include legal protection for well-know marks of both like and unlike products. The courts based their considerations upon good faith principle.
\end{abstract}

\section{Pendahuluan}

Perkara merek atau sengketa merek yang terjadi di Indonesia hingga hari ini didominasi oleh gugatan pembatalan merek dan gugatan ganti rugi yang berkaitan dengan pelanggaran merek terkenal. Perkembangan perkara gugatan merek dapat diikuti dari Perkara PT Tancho Indonesia melawan Wong A Kiong mengenai Merek Tancho hingga perkara PT Nabisco Foods melawan PT Perusahaan Dagang dan Industri Ceres mengenai merek Ritz.

Banyaknya penggunaan merek terkenal oleh beberapa pengusaha domestik atau lokal tidak lepas kaitannya dengan betapa pentingnya merek tersebut bagi suksesnya pemasaran suatu produk barang atau jasa. Menurut Insan Budi Maulana, merek dapat dianggap sebagai "roh" bagi suatu produk barang atau jasa.' Merek sebagai 'tanda pengenal dan tanda pembeda akan dapat menggambarkan jaminan kepribadian (individuality) reputasi barang dan jasa hasil usahanya sewaktu diperdagangkan. $^{2}$

'Insan Budi Maulana. 1997. Sukses Bisnis melalui Merek, Paten, dan Hak Cipta. Bandung: Citra Aditya Bakti. HIm 60 .

${ }^{2}$ Wiratmo Dianggoro: 1997. "Pembaharuan UU Merek dan Dampaknya bagi Dunia Bisnis". artikel pada Jurnal Hukum Bisnis. Volume 2. HIm 34. 
Dari sisi produsen, merek digunakan sebagai jaminan nilai hasil produksinya, khususnya mengenai kualitas pemakaiannya. Dari segi pedagang, merek digunakan untuk promosi barang-barang dagangannya guna mencari dan meluaskan pasar. Dari sisi konsumen, merek diperlukan untuk melakukan pilihanpilihan barang yang akan dibeli. ${ }^{3}$ Bahkan, terkadang penggunaan merek tertentu bagi seorang konsumen dapat menimbulkan image tertentu.

Tidak dapat dibayangkan apabila suatu produk yang tidak memiliki merek, tentu produk yang bersangkutan tidak akan dikenal oleh konsumen. Oleh karenaitu, suatu produk apakah produk itu baik atau tidak tentu akan memiliki merek. Bahkan, tidak mustahil, merek yang telah dikenal luas oleh konsumen karena mutu dan harganya akan selalu dilkuti, ditiru, "dibajak" bahkan mungkin dipalsukan oleh produsen lain yang melakukan persaingan curang. ${ }^{4}$

Penggunaan merek terkenal secara melawan hukum yang marak terjadi di Indonesia tidak dapat dipisahkan dari mental pengusaha lokal yang "potong kompas" dan tanpa usaha yang cukup untuk mengembangkan merek yang mereka buat sendiri. Idealnya pengusaha lokal memang harus memiliki merek sendiri dan mengembangkannya hingga memiliki reputasi tinggi dan menjadi merek terkenal. Akan tetapi, hal tersebut akan memakan waktu yang cukup lama. Untuk menjadikan suatu merek menjadi merek terkenal yang mampu menunjukkan jaminan kualitas atau reputasi suatu produk tentu tidak mudah dan memeriukan waktu yang cukup lama dan biaya yang tidak sedikit pula. Coca Cola merek minuman ringan dari Amerika Serikat memerlukan waktu 100 (seratus) tahun, Toyota perlu waktu 30 (tiga puluh) tahun, dan McDonald 40 (empat puluh) tahun lebih. ${ }^{5}$

Apabila suatu merek telah menjadi terkenal tentu akan menjadikan merek tersebut'sebagai asset atau kekayaan perusahaan yang penting nilainya. Akan tetapi di lain pihak, keterkenalan tersebut akan memancing produsen lain yang menjalankan perilaku bisnis curang untuk "membajak" atau menirunya.

Permasalahan pelanggaran dan perlindungan merek terkenal tidak hanya terjadi di Indonesia, tetapi juga di berbagai negara lain. Misalnya di Swedia (kasus Friskis och Svettis, 1991), Jerman (kasus Bally vs Ball, 1991), Perancis (kasus Ungaro, 1991 atau Rochas, 1991), Inggris (Elderflower Champagne, 1993) dan di Jepang (kasus Loreley, 1991). Akan tetapi masalah terkenal di Indonesia mempunyai keunikan tersendiri, karena pemilik merek terkenal yang sebenarnya justru digugat oleh pihak lokal, misalnya dalam kasus Piere Cardin dan Levi's. ${ }^{6}$ Problematika pelanggaran merek terkenal dan upaya perlindungan hukumnya sebenarnya bukanlah masalah baru. Prolematika tersebut hampir seumur dengan perjalanan sejarah Paris Convention for the Protection of Industrial Property Tahun 1883 yang biasa disebut dengan Konvensi Paris.

\footnotetext{
3/bid

${ }^{4}$ Insan Budi Maulana. Loc.Cit.

5Lihat Ekbis. Suplemen Harian Umum Republika. Senin 7 Desember 1998.

'Insan Budi Maulana. Op. Cit. HIm 97.
} 
Upaya untuk memberikan perlindungan hukum bagi merek terkenal di dalam Konvensi Paris sendiri dilakukan melalui amandemen terhadap konvensi tersebut dalam konferensi di Den Haag pada tahun 1925. Amandemen Konvensi Paris tersebut melahirkan Pasal 6 bis Konvensi Paris. Upaya berikutnya dilakukan melalui berbagai perundingan dalam Putaran Perundingan Uruguay (Uruguay Round) yang antara lain menghasilkan kesepakatan Agreement on Trade Related Aspects of Intellectual Property Rights (TRIPS)

\section{Merek Terkenal}

Berdasarkan reputasi (reputation) dan kemashuran (renown) suatu merek, merek dapát dibedakan dalam tiga jenis, yakni merek biasa (normal marks), merek terkenal (wellknown marks), dan merek termashur (famous marks). Merek biasa adalah merek yang tergolong tidak memiliki reputasi tinggi. Merek yang berderajat "biasa" ini dianggap kurang memberi pancaran simbolis gaya hidup baik dari segi pemakaian dan teknologi, masyarakat konsumen melihat merek tersebut kualitasnya rendah. Merek ini jüga dianggap tidak memiliki drawing power yang mampu memberi sentuhan keakraban dan kekuatan mitos (mythical power) yang sugestif kepada masyarakat konsumen, dan tidak mampu membentuk lapisan pasar dan pemakai. ${ }^{j}$

Di atas merek biasa terdapat merek terkenal, yakni merek yang memiliki reputasi tinggi. Merek yang demikian itu memiliki kekuatan pancaran yang memukau dan manarik, sehingga jenis barang apa saja yang berada di bawah merek itu langsung menimbulkan sentuhan keakraban (familiar attachement) dan ikatan mitos (mythical context) kepada segala lapisan konsumen. ${ }^{8}$ Tingkat derajat merek yang tertinggi adalah merek termashur. Sedemikian rupa mashumya di seluruh dunia, mengakibatkan reputasinya digolongkan sebagai "merek aristokrat dunia". ${ }^{9}$ Dalam kenyataannya sangatlah sulit membedakan antara merek terkenal dan merek termashur. Kesulitan dalam penafsiran, mengakibatkan kesulitan menentukan batas dan ukuran di antara keduanya. Jika merek termashur didasarkan pada ukuran "sangat terkenal dan sangat tinggi reputasinya", pada dasarnya ukuran seperti itu juga dimiliki oleh merek terkenal. Oleh karena itu, bagi yang mencoba membuat definisi merek termashur, besar sekali kemungkinannya akan terjebak dengan perumusan yang tumpang tindih dengan definisi merek terkenal. ${ }^{10}$

Baik berdasarkan konvensi-konvensi internasional dan peraturan perundang-undangan nasional di bidang.merek, pada dasarnya hanya mengenal merek biasa dan merek terkenal. Menurut Bambang Kesowo," hingga saat

${ }^{7}$ M. Yahya Harahap. 1996. Tinjauan Merek Secara Umum dan Hukum Merek di Indonesia Berdasarkan Undang-Undang Nomor 19 Tahun 1992. Hilm 80 -81.

$8 /$ bid. HIm $82-83$.

Ibid. HIm 85.

${ }^{10} /$ bid. HIm 86.

"Bambang Kesewo. 1998. pidato sambutan arahan pada Seminar Nasional Porlindungan Merek Terkenal di Indonesia. Fakultas Hukum Universitas Parahyangan - Perhimpunan Masyarakat HAKI indonesia- United States Information Service. Bandung. 26 September 1998. HIm 1. 
ini sebenarnya tidak ada definisi merek terkenal yang dapat diterima secara luas. Bahkan, upaya-upaya untuk menginventarisasi unsurunsur yang membentuk pengertian itu pun hingga kini belum memperoleh kesepakatan. Oleh karenanya, kalau ada pihak yang selalu mendesakkan pengertian yang dimilikinya atau diakuinya terhadap pihak lain, hal itu hanyalah semata-mata karena adanya kepentingan pemilik merek yang bersangkutan. Bahkan, selama perundingan Putaran Uruguay di bidang TRIPs berlangsung hingga berakhir dan ditandatanganinya persetujuan Pembentukan WTO, tidak satu negara pun mampu membuat dan mengusulkan definisi merek terkenal tersebut. ${ }^{12}$ Pasal 1 Keputusan Menteri Kehakiman Republik Indonesia Nomor: M-02-HC.01.01 Tahun 1987 mendefinisikan merek terkenal sebagai merek dagang yang telah lama dikenal dan dipakai di wilayah Indonesia oleh seseorang atau badan untuk jenis barang tertentu. Keputusan Menteri Kehakiman di atas kemudian diperbaharui dengan Keputusan Menteri Kehakiman RI No. M.03-HC.02.01.Tahun 1991. Pasal 1 Keputusan Menteri Kehakiman yang belakangan ini mendefinisikan merek terkenal sebagai merek dagang yang secara umum telah dikenal dan dipakai pada barang yang diperdagangkan oleh seseorang atau badan, baik di wilayah Indonesia maupun di luar negeri. Hukum Merek Indonesia sebagaimana diatur UU Nomor 19 Tahun 1992 jo UU Nomor 14 Tahun 1997 tidak memberikan definisi merek terkenal. Penjelasan Pasal 6 UU Merek hanya memberikan kriteria merek terkenal.

\section{Pengaturan Merek Terkenal di dalam Konvensi Paris dan TRIPs}

Sebagaimana telah disebutkan di atas, bahwa permasalahan upaya perlindungan hukum terkenal ini bukanlah permasalahan yang baru. Ketentuan mengenai perlindungan merek terkenal di dalam Konvensi Paris telah dimuat di dalam amandemen Konvensi Paris ketika dilakukan konferensi diplomatik mengenai amandemen dan revisi Konvensi Paris di Den Haag pada tahun 1925. Setelah beberapa kali mengalami revisi, rumusan Pasal 6 bis Konvensi Paris berbunyi sebagai berikut:

"(1) The countries of the Union undertake, ex officio of their legislation so permits, or at the request on an interested party, to refuse or to cancel the registration and to prohibit the use of a trademark which constitutes a reproduction, an imitation, or a trans/ation, liable to create confusion, of a mark considered by the competent authority of the country registration or to use to be wellknown in that country as being already the marks of a person entitled to the benefit of this Convention and used for identical or similar goods. These provision shall also apply when the es: sential part of the mark contitutes a reproduction of any such well-known mark or imitation liable to create confusion therewith.

\footnotetext{
12/bid. Hlm 3.
} 
(2) A period of at least five years from the date of registration shall be allowed for requesting the cancellation of such a marks. The countries of the union may provided for a period within which the prohibition of use must be requested

(3) No time limit shall be fixed for seaking the cancellation or the prohibition of use of marks registreted or used in bad faith.

Menurut Bambang Kesowo prinsip yang diatur dalam Pasal 6 bis Konvensi Paris tersebut masih begitu sederhana:13

1. Negara Peserta diminta menolak, baik atas perundang-undangan (merek) yang dimiliki, atau atas dasar perundang undangan (merek) yang dimiliki, atau atas dasar permintaan pihak yang berkepentingan, permintaan pendaftaran atau membatalkan pendaftaran, dan melarang penggunaan merek yang sama dengan, atau merupakan tiruan dari, atau dapat menimbulkan kebingungan (dan seterusnya) dari suatu merek yang:

a. menurut pertimbangan pihak yang berwenang di negara penerima pendaftaran merupakan merek terkenal atau telah dikenal luas sebagai merek milik seseorang yang berhak memperoleh perlindungan sebagaimana diatur dalam konvensi;

b. digunakan pada produk yang sama atau sejenis.
2. jangka waktu untuk minta pembatalan setidaknya lima tahun terhitung sejak tanggal pendaftaran (merek yang menyerupai merek terkenal tadi); dan

3. kalau pendaftaran dilakukan dengan iktikad buruk, tidak ada batas waktu untuk memintakan pembatalan.

Pasal 6 bis Konvensi Paris tersebut kemudian diadopsi Pasal 16 ayat (2) dan (3) TRIPs:

(2) Article 6 bis of the Paris Convention (1967) shall appy, mutatis mutandis to services. In the dermining whether a trademarks is well-known, Members shall take account of the knowledge of a trademarks in the relevant sector of the public including knowledge in the Member concerned which has been obtained as a result of the promotion of the trade mark.

(3) Article 6 bis of the Paris Convention (1967) shall apply, mutatis mutandis, to goods or services which are not similar to those in respect of which trademarks is registered, provided that use that trademarks in relation to those goods or services would indicate a connection between those goods or services and the owner of the registered trademarks and provided that the interest of the owner of the registered trademarks are likely to be damaged by such use.

${ }^{13}$ bid. HIm 5. 


\section{Kriteria Merek Terkenal}

Kriteria merek terkenal yang dianut di Amerika Serikat diatur dalam Pasal 43 (c) (1) Lannham Act yang diperbaharui menentukan bahwa untuk menentukan apakah suatu merek mempunyai sifat daya pembeda dan terkenal, Pengadilan dapat mempertimbangkan faktorfaktor seperti, tetapi tidak terbatas pada):14

1. derajad sifat yang tidak terpisahkan atau mempunyai sifat daya pembeda dari merek tersebut;

2. jangka waktu dan ruang lingkup pemakaian merek yang berkaitan dengan barang atau jasa dari merek;

3. jangka waktu dan ruang lingkup dari pengiklanan dan publisitas merek tersebut;

4. ruang lingkup geografis dari daerah perdagangan di mana merek tersebut . dipakai;

5. jaringan perdagangan barang atau jasa dari merek yang dipakai;

6. derajad pengakuan atas merek tersebut dari arena perdagangan dan jaringan perdagangan dari pemilik merek dan larangan terhadap orang atas pemakaian merek tersebut dilaksanakan;

7. sifat umum dan ruang lingkup pemakaian merek yang sama oleh pihak ketiga; dan

8. keberadaaan pendaftaran merek tersebut berdasarkan Undang-Undang Tanggal 3 Maret 1981 atau Undang-Undang Tanggal 20 Pebruari 1905 atau pendaftaran pertama.
Kriteria.yang lebih rinci juga dimiliki Kantor Merek China. dalam menentukan terkenal tidaknya suatu merek, yakni:15

1. ruang lingkup daerah geografis di mana merek tersebut dipakai;

2. jangka waktu merek tersebut dipakai;

3 jumlah dan hasil minimum penjualan dari pemakaian merek;

4. pengetahuan masyarakat tentang merek tersebut;

5. status merek tersebut apakah telah terdaftar di negara lain;

6. biaya pengeluaran dari iklan berikut daerah jangkauan iklan tersebut;

7. usaha-usaha yang telah dilakukan oleh pemilik merek dalam melindúngi merek tersebut; dan

8. kemampuan pemilik merek untuk mempertahankan kualitas yang baik dari merek yang dipakainya.

Sebagaimana telah dijelaskan di atas bahwa hingga sekarang belum didapat satu definisi merek terkenal yang dapat diterima secara umum. Pasal 16 ayat (2) TRIPs sendiri hanya berhasil membuat kriteria sifat keterkenalan suatu merek, yakni dengan memperhatikan faktor pengetahuan tentang merek di kalangan tertentu dalam masyarakat, termasuk pengetahuan negara peserta tentang kondisi merek yang bersangkutan, yang diperoleh dari hasil promosi merek tersebut. Ketentuan Pasal 12 ayat (2) TRIPs tersebut kemudian diadopsi oleh Penjelasan Pasal 6 Undang-Undang Merek Indonesia. Walaupun UU Merek Indo-

${ }^{14}$ Iman Syahputra, et.al. 1997. Hukum Merek Baru Merek Indonesia Seluk Beluk Tanya Jawab. Jakarta: Harvarindo. HIm $21-22$.

${ }^{15} /$ bid. 
nesia juga belum berhasil membuat definisi merek terkenal, namun telah mencoba memberikan kriteria merek terkenal. Penjelasan Pasal 6 UU Merek menentukan bahwa kriteria merek terkenal, selain memperhatikan pengetahuan umum masyarakat, penentuannya juga didasarkan pada reputasi merek yang bersangkutan yang diperoleh karena promosi yang dilakukan oleh pemiliknya yang disertai dengan bukti pendaftaran merek tersebut di beberapa negara (jika ada). Apabila hal-hal di atas belum dianggap cukup, maka hakim dapat memerintahkan lembaga yang bersifat mandiri (independent) untuk melakukan survei guna memperoleh kesimpulan mengenai terkenal atau tidaknya merek yang bersangkutan.

Tambahan mengenai kemungkinan dilakukannya survei oleh suatu lembaga independen mengenai keterkenalan suatu merek mengikuti pola yang dianut di Jerman, $\mathrm{Pe}$ rancis, dan Italia. Di Jerman sebagaimana dikatakan Iman Syahputra ${ }^{16}$, Pengadilan berpatokan pada survei pasar yang dilakukan secara objektif. Apabila survei pasar membuktikan bahwa lebih dari $80 \%$ (delapan puluh persen) masyarakat mengenal dan mengetahui merek yang diselidiki, maka merek tersebut adalah merek terkenal. Sedangkan di Perancis, penentuan terkenal hanya didasarkan pada poll $20 \%$ (dua puluh persen) dari masyarakat yang mengetahui dan mengenal merek tersebut.

Menyadari kekurangan dalam persetujuan TRIPs di atas, dan timbulnya semacam antipati yang kurang menguntungkan, kembali dihidupkan jalur WIPO melalui prakarsa pembuatan persetujuan baru di bidang merek yang dirancang khusus bagi Protection of WellKnown Marks. Persetujuan tersebut hingga kini masih dirundingkan, dan khusus dibuat untuk memberi jabaran rinci tentang merek terkenal saja. ${ }^{17}$ Di dalam rancangan persetujuan yang dirundingkan tersebut, setidaknya akan hadir dua norma baru, yakni: ${ }^{18}$

1. Upaya memperjelas pengertian relevant sector of the public (kalangan masyarakat tertentu) dalam kaitannya dengan merek terkenal dengan mengajukan identifikasi dalam dua unsur penentu: a. hanya terbatas pada konsumen potensial saja; dan b. jaringan distribusi dan lingkungan bisnis yang biasa dengan merek terkenal pada umumnya.

2. Upaya penentuan elemen untuk membangun pengertian merek terkenal yang meliputi 12 (dua belas) unsur, yakni: a. jangka waktu, lingkup, dan wilayah penggunaan merek; b. pasar; c. tingkat daya pembeda; d. kualitas nama baik (image); $e$. luas sebaran pendaftaran di dunia; $f$. sifat eksklusivitas pendaftaran yang dimiliki; g. luas sebaran penggunaan di dunia; h. tingkat eksklusivitas penggunaan di dunia; i. nilai perdagangan dari merek yang bersangkutan di dunia; j. rekor perlindungan hukum yang berhasil diraih; $k$. hasil litigasi dalam penentuan terkenal tidaknya suatu merek; dan I. intentisitas pendaftaran merek lain yang mirip dengan merek yang . bersangkutan.

${ }^{16} /$ bid. HIm 24.

${ }^{17}$ Bambang Kesowo. Op.Cit. HIm 8.

${ }^{18} /$ bid. 


\section{Perlindungan Hukum Preventif}

Menurut Penjelasan Umum UU Nomor 14 Tahun 1997, perlindungan terhadap merek terkenal didasarkan pada pertimbangan bahwa peniruan merek terkenal milik orang lain pada dasarnya dilandasi iktikad tidak baik, terutama untuk mengambil kesempatan dari ketenaran merek orang lain, sehingga tidak seharusnya mendapat perlindungan hukum. Berdasarkan undang-undang ini, mekanisme perlindungan merek terkenal, selain melalui inisiatif pemilik merek tersebut sebagaimana telah diatur dalam Pasal 56 ayat (3) UU Nomor 19 Tahun 1992, dapat pula ditempuh melalui penolakan oleh Kantor Merek terhadap permintaan pendaftaran merek yang sama pada pokoknya dengan merek terkenal. Perlindungan hukum merek yang diberikan baik kepada merek asing atau lokal, terkenal atau tidak terkenal hanya diberikan kepada merek terdaftar.

Sehubungan dengan hal tersebut di atas, Pasal 3 UU Merek menyatakan bahwa hak atas merek adalah khusus yang diberikan oleh negara kepada pemilik merek yang terdaftar dalam Daftar Umum Merek untuk jangka waktu tertentu. Kemudian Pasal 7 UU Merek menambahkan lagi, bahwa merek terdaftar mendapat perlindungan hukum untuk jangka waktu 10 (sepuluh) tahun dan berlaku surut sejak tanggal penerimaan pendaftaran merek (filing date) yang bersangkutan. Sebenarnya tidak ada kewajiban bagi seseorang untuk mendaftarkan merek yang ia miliki. la bebas mendaftar atau tidak mendaftarkan merek yang bersangkutan. Akan tetapi jika akan mendapatkan perlindungan hukum berdasarkan hukum merek, maka merek yang bersangkutan harus terdaftar terlebih dahulu.

Suatu permohonan pendaftaran merek akan diterima pendaftarannya apabila telah memenuhi persyaratan baik yang bersifat formalitas maupun substantif yang telah ditentukan UU Merek. Syarat utama yang sekaligus menjadi ciri utama suatu merek adalah adanya daya pembeda (distinctiveness) yang cukup. Merek yang dipakai haruslah sedemikian rupa, mempunyai cukup kekuatan untuk membedakan barang atau jasa suatu perusahaan dengan barang atau jasa yang diproduksi perusahaan lainnya.

Sehubungan dengan hal tersebut di atas, Pasal 5 UU Merek menentukan bahwa merek tidak dapat didaftar apabila mengandung salah satu unsur di bawah ini:

1. bertentangan dengan kesusilaan dan ketertiban umum;

2. tidak memiliki daya pembeda;

3. telah menjadi milik umum; atau

4. merupakan keterangan atau berkaitan dengan barang atau jasa yang dimintakan pendaftaran.

Persyaratan yang ditentukan Pasal 5 UU Merek tersebut harus ditambah dengan persyaratan yang ditentukan Pasal 6 UU Merek. Menurut Pasal 6 ayat (1) UU Merek, permintaan pendaftaran merek harus ditolak oleh Kantor Merek apabila mempunyai persamaan pada pokoknya atau keseluruhannya dengan merek milik orang lain yang sudah terdaftar untuk barang atau jasa yang sejenis.

Kata kunci Pasal 6 ayat (1) UU Merek tersebut adalah persamaan pada keseluruhan, persamaan pada pokoknya, dan merek orang lain yang telah terdaftar. Persamaan pada keseluruhannya adalah persamaan keseluruhan elemen. Persamaan yang demikian sesuai dengan ajaran doktrin entires similar atau sama keseluruhan elemen. Dengan perkataan lain, merek yang dimintakan pendaftarannya me- 
rupakan copy atau reproduksi merek orang lain. ${ }^{19}$ Supaya suatu merek dapat disebut sebagai copy atau reproduksi merek orang lain, sehingga dikualifikasi mengandung persamaan secara keseluruhan, paling tidak harus dipenuhi syarat-syarat sebagai berikut:20

1. terdapat persamaan elemen secara keseluruhan;

2. persamaan jenis atau produksi kelas barang atau jasa;

3. persamaaan wilayah dan segmen pasar;

4. persamaan cara dan perilaku pemakaian; dan

5. persamaan cara pemeliharaan.

Suatu merek dianggap mempunyai persamaan pada pokoknya dengan merek orang lain ditentukan berdasarkan patokan yang lebih lentur dibanding dengan doktrin entires similar. Persamaan pada pokoknya dianggap terwujud apabila merek tersebut memiliki kemiripan (identical) hampir mirip (nearly resembles) dengan merek orang lain. Kemiripan tersebut dapat didasarkan pada:21

1. kemiripan persamaan gambar;

2. hampir mirip atau hampir sama susunan kata, warna, atau bunyi;

3. faktor yang paling penting dalam doktrin ini, pemakaian merek menimbulkan kebingungan (actual confusion) atau menyesatkan (decive) masyarakat konsumen. Seolah-olah merek tersebut dianggap sama sumber produksi dan sumber asal geografis dengan barang milik orang lain (likelihood confusion).
Menurut Penjelasan Pasal 6 ayat (1) UU Merek, yang dimaksud "sama pada pokoknya" dengan merek terdaftar orang lain tersebut adalah adanya kesan yang sama, antara lain mengenai bentuk, cara penempatan atau kombinasi antara unsur-unsur maupun bunyi ucapan yang terdapat di dalam merek yang bersangkutan. Pasal 6 ayat (2) UU Merek menambahkan lagi bahwa pendaftaran merek juga harus ditolak oleh Kantor Merek apabila:

1. merupakan atau menyerupai nama orang terkenal, foto, dan nama badan hukum yang dimiliki orang lain, kecuali atas persetujuan tertulis dari yang berhak;

2. merupakan peniruan atau menyerupai nama, atau singkatan nama, bendera, lambang atau simbul atau emblem, dari negara atau lembaga nasional maupun internasional, kecuali atas persetujuan tertulis dari pihak yang berwenang;

3. merupakan peniruan atau menyerupai tanda atau cap atau stempel resmi yang digunakan negara atau lembaga pemerintah, kecuali atas persetujuan dari pihak yang berwenang; atau

4. merupakan atau menyerupai ciptaan orang lain yang dilindungi Hak Cipta, kecuali atas persetujuan pemegang hak cipta tersebut.

Kantor merek juga menurut Pasal 6 ayat (3) dapat menolak pendaftaran merek yang mempunyai persamaan pada pokoknya atau keseluruhannya dengan merek orang yang sudah terkenal milik orang lain untuk barang

${ }^{19}$ M. Yahya Harahap. Op.Cit. HIm. 416.

${ }^{20} /$ bid.

21/bid. HIm. 417. 
atau jasa yang sejenis. Menurut Pasal 6 ayat (4) ketentuan sebagaimana diatur dalam ayat (3) dapat pula diberlakukan terhadap barang atau jasa yang tidak sejenis sepanjang dipenuhi persyaratan tertentu yang ditetapkan lebih lanjut dengan Peraturan Pemerintah. Hingga hari ini Peraturan Pemerintah yang dimaksud Pasal 6 ayat (4) tersebut belum ada.

Apabila permohonan pendaftaran merek tersebut memenuhi persyaratan formalitas, masa pengumuman, persyaratan substantif, maka dapat diberikan sertifikat merek dan kemudian didaftarkan dalam Daftar Umum Merek. Dengan telah diterimanya Sertifikat Merek dan didaftarkannya merek yang bersangkutan di dalam Daftar Umum Merek, maka pemilik merek terdaftar tersebut memiliki hak eksklusif (exclusive right) sebagaimana dimaksud Pasal 3 UU Merek. Hak eksklusif tersebut dapat berupa hak menikmati secara eksklusif (exclusive enjoyment) maupun hak eksklusif untuk mengeksploitasi keuntungan exclusive financial exploitation).

\section{Perlindungan Hukum Refresif}

Pemilik merek terdaftar mendapat perlindungan hukum atas pelanggaran hak atas merek baik dalam wujud gugatan ganti rugi (dan gugatan pembatalan pendaftaran merek) maupun berdasarkan tuntutan hukum pidana melalui aparat penegak hukum.

Perlindungan hukum yang refresif ini diberikan apabila telah terjadi pelanggaran hak atas merek. Di sini peran lembaga peradilan dan aparat penegak hukum lainnya seperti kepolisian, penyidik pegawai negeri sipil (PPNS), dan kejaksaan sangat diperlukan.

Pasal 72 ayat (1) UU Merek memberikan hak kepada pemilik merek terdaftar untuk mengajukan gugatan terhadap orang atau badan hukum yang secara tanpa hak menggunakan merek barang dan atau jasa yang mempunyai persamaan pada pokoknya atau keseluruhannya dengan mereknya. Gugatan tersebut menurut Pasal 72 ayat (2) harus diajukan melalui Pengadilan Negeri sebagaimana dimaksud Pasal 52 UU Merek, yakni Pengadilan Negeri Jakarta Pusat dan Pengadilan Negeri yang lain yang akan ditetapkan dengan $\mathrm{Ke}$ pułusan Presiden. Namun karena hingga hari ini Keputusan Presiden yang dimaksud belum ada, maka praktis yang memiliki kompetensi atau yurisdiksi mengadili gugatan perdata sengketa merek tersebut hanyalah Pengadilan Negeri Jakarta Pusat.

Menurut Pasal 74 ayat (1) UU Merek, atas permintaan pemilik merek atau penerima lisensi merek terdaftar selaku. penggugat, selama masih dalam pemeriksaan dan untuk mencegah kerugian yang lebih besar, hakim dapat memerintahkan tergugat untuk menghentikan perdagangan barang atau jasa yang menggunakan merek secara tanpa hak tersebut. Selain itu menurut Pasal 74 ayat (2) UU Merek, dalam hal tergugat dituntut pula menyerahkan barang yang akan menggunakan merek secara tanpa hak, hakim dapat memerintahkan bahwa penyerahan barang atau nilai barang tersebut dilaksanakan setelah putusan pengadilan mempunyai kekuatan hukum tetap dan setelah penggugat membayar harganya kepada tergugat. Selain memiliki hak untuk melakukan gugatan secara keperdataan tersebut, pemilik merek juga mendapat perlindungan hukum yang lain. Menurut Pasal 76 UU Merek, hak untuk mengajukan gugatan tersebut tidak akan mengurangi hak negara untuk melakukan tuntutan tindak pidana di bidang merek. 
Perlindungan hukum yang diberikan oleh UU Merek kepada pemilik berdasar ketentuan hukum pidana merek melalui Pasal 81,82 , $82 \mathrm{~A}, 83$, dan 84. Pasal 81 UU Merek menegaskan barang siapa yang dengan sengaja dan tanpa hak menggunakan merek yang sama pada pokoknya dengan milik terdaftar milik orang lain atau badan hukum lain, untuk barang atau jasa yang sejenis yang diproduksi atau diperdagangkan dengan ancaman pidana penjara paling lama 7 (tujuh) tahun dan denda paling banyak Rp $50.000 .000,00$ (lima puluh juta). Sedangkan Pasal 82 memberikan ancaman pidana penjara paling lama 5 (lima) tahun dan denda paling banyak Rp 50.000.000,00 (lima puluh juta) bagi barang siapa yang sengaja dan tanpa hak menggunakan merek terdaftar milik orang lain atau badan hukum lain.

Pengaturan sanksi yang diatur Pasal $82 \mathrm{~A}$ dan 82 B UU Merek berkaitan perluasan lingkup merek yang dilindungi yakni indikasi geografis dan Indikasi Asal. Kedua pasal ini sama-sama memberikan ancaman maksimal sebagaimana diatur Pasal 81 dan 82 . Semua tindak pidana di atas oleh Pasal 83 UU Merek dikategorikan sebagai kejahatan.

Ketentuan sanksi pidana lainnya dijumpai dalam Pasal 84 ayat (1) UU Merek yang mengatur bahwa barang siapa yang memperdagangkan barang atau jasa yang diketahui atau patut diketahui bahwa barang atau jasa tersebut merupakan hasil pelanggaran sebagaimana dimaksud Pasal 81, 82, $82 \mathrm{~A}$, dan $82 \mathrm{~B}$ dipidana dengan pidana kurungan paling lama 1 (satu) tahun atau denda paling banyak Rp10.000.000,00 (sepuluh juta ru- piah). Tindak pidana sebagaimana dimaksud Pasal 84 ayat (1) di atas dikategorikan sebagai pelanggaran.

Selain adanya tuntutan ganti rugi melalui gugatan perdata maupun penjatuhan sanksi pidana. Pemilik merek memiliki hak untuk mengajukan pembatalan merek. Gugatan pembatalan merek ini dilakukan apabila ternyata yang dimiliki seseorang (termasuk merek terkenal) ternyata telah juga didaftarkan pada Kantor Merek. Gugatan pembatalan tersebut menurut Pasal 56 UU Merek harus diajukan oleh pihak yang berkepentingan berdasarkan alasan sebagaimana dimaksud Pasal 4 ayat (1), Pasal 5 atau Pasal 6.

Gugatan Pembatalan tersebut hanya dapat diajukan oleh pemilik terdaftar. Namun khusus bagi pemilik merek terkenal, pemilik merek terkenal tidak terdaftar pun dapat mengajukan gugatan pembatalan merek tersebut setelah mengajukan permintaan pendaftaran merek kepada Kantor Merek. ${ }^{22}$

\section{Simpulan}

Perlindungan hukum merek terkenal yang diberikan UU Merek yang bersifat preventif, yakni berkaitan dengan pendaftaran merek sudah selaras dengan ketentuan TRIPs sebagaimana ditentukan Pasal 6 ayat (3) dan (4) mencakup perlindungan terhadap barang atau jasa baik yang sejenis maupun bukan. Namun yang berkaitan dengan perlindungan yang bersifat refresif masih belum terpecahkan.

Pasal 72 UU Merek menentukan bahwa pemilik merek terdaftar dapat mengajukan gugatannya terhadap orang atau badan hukum

\footnotetext{
22Lihat Pasal 56 ayat (2) dan (3) UU Merek.
} 
yang secara tanpa hak menggunakan merek untuk barang dan atau jasa yang sejenis yang mempunyai persamaan pada pokoknya atau keseluruhannya dengan merek. Ketentuan Pasal 72 membatasi pelanggaran merek hanya terhadap barang atau jasa yang sejenis saja. Demikian juga yang berkaitan sanksi pidananya juga didasarkan pada pelanggaran pidananya juga pelanggaran merek untuk barang atau jasa yang sejenis.

Dengan demikian dapat disimpulkan bahwa Ündang-Undang Merek Indonesia yang berkaitan dengan perlindungan yang bersifat refresif membatasi dirinya bagi perlindungan hukum bagi barang atau jasa yang sejenis saja. Padahal di dalam kenyataannya beredar banyak barang yang menggunakan merek terkenal yang sudah terdaftar secara tanpa hak, tetapi digunakan pada barang yang tidak sejenis. Pada masa sebelum berlakunya UU Nomor 19 Tahun 1992 jo UU No.14 Tahun 1997 sebenarnya dalam banyak kasus, pengadilan telah memperluas perlindungan hukum merek tersebut, yakni mencakup perlindungan hukum bagi merek terkenal baik untuk barang yang sejenis maupun bukan. Pengadilan mendasarkan pandangannya dengan prinsip iktikad baik. Ada niat yang tidak baik (iktikad buruk) untuk membonceng ketenaran merek orang lain. ${ }^{23} \square$

\section{Daftar Pustaka}

Gautama, Sudargo dan Rizawanto Winata. 1987. Himpunan Keputusan Merek Dagang. Alumni. Bandung.

Harahap, M.Yahya. 1996. Tinjauan Merek Secara Umum dan Hukum Merek di Indonesia Berdasarkan Undang-Undang No. 19 Tahun 1992. Citra Aditya Bakti: Bandung.

Kesowo, Bambang. Sambutan Arahan pada Seminar Nasional Perlindungan - Merek Terkenal di Indonesia. Fakultas Hukum Universitas Parahyangan Perhimpunan Masyarakat HAKI Indonesia - United States Information Service. Bandung 26 September 1998.

Maulana, Budi Insan.1997. Sukses Bisnis Melalui Merek, Paten, dan Hak Cipta. Citra Aditya Bakti:Bandung.

Syahputra, Iman, et.ai. 1997. Hukum Merek Baru Indonesia: Seluk Beluk Tanya Jawab. Jakarta: Harvarindo.

Jurnal Hukum Bisnis. 1997. Jakarta: Yayasan Pengembangan Hukum Bisnis. Edisi Volume 2 - 1997.

Undang-Undang Nomor 19 Tahun 1992.

Undang-Undang 14 Tahun 1997.

Konvensi Paris

Trade Related Aspects of Intellectual Property Rights

Ekbis. Suplemen Harian Umum Republika.

- Edisi Senin 7 Desember.

${ }^{23}$ Perhatikan Putusan Pengadilan Negeri Jakarta Pusat No.242/1980 Tanggal 21 Agustus 1981 mengenai perkara Richard Dunhill dan John Wood melawan Lilien Sutan dan Pemerintah Indonesia tentang merek Dunhill. Keputusan Pengadilan Jakarta Pusat tersebutkemudian dikuatkan Mahkamah Agung melalui Putusannya tanggal 1984 Register No. 370 KISip/1983. Lihat Sudargo Gautama dan Rizawanto Winata. 1987. Himpunan Keputusan Merek Dagan. Alumni. Bandung. HIm 97-108. 